\section{REVIEW ARTICLE}

\title{
Microarrays for microbiologists
}

\author{
S. Lucchini, A. Thompson and J. C. D. Hinton
}

Author for correspondence: J. C. D. Hinton. Tel: +44 1603 255352. Fax: +44 1603255076. e-mail: jay.hinton@bbsrc.ac.uk

Molecular Microbiology, Institute of Food Research, Norwich Research Park, Norwich NR4 7UA, UK

Keywords: DNA microarray, gene expression profiling, microbial genomotyping

\section{Background}

We are witnessing a remarkable change in the scale of molecular microbiological research and we are entering an era of 'big science'. In the past decade we have moved from a time when entire research papers were based on the sequencing of a single gene or operon to a single paper describing the sequence of a whole genome. The completion of microbial genomes is continuing apace, with 37 genome sequences completed, and 142 in progress worldwide (http://www.tigr.org/tdb/mdb/ mdbcomplete.html). The availability of this level of genetic information has spawned the terms 'functional genomics', 'transcriptomics' (Velculescu et al., 1997) and 'proteomics' (Wasinger et al., 1995), which describe the large-scale application of mass mutagenesis, gene expression profiling and global protein analysis. In this review we assess the role that gene expression profiling has begun to play in microbiology, discuss the potential for 'genomotyping' and consider future applications.

Assessment of transcription at the genomic scale has been achieved with DNA microarrays, which are glass slides containing an ordered mosaic of the entire genome as a collection of either oligonucleotides (oligonucleotide microarrays) or PCR products representing individual genes (commonly referred as cDNA microarrays).

The development of microarrays has been fuelled by the application of robotic technology to routine molecular biology, rather than by any fundamental breakthrough. The classical Southern and Northern blotting approaches for the detection of specific DNA and mRNA species (Southern, 1975; Alwine et al., 1977, 1979) provided the technological basis for microarray hybridization with fluorescently labelled cDNA. The idea of depositing multiple DNA spots representing different genes onto a solid surface is also nothing new, having been used by Blattner's group to investigate Escherichia coli gene expression on membranes (macroarrays) as long ago as 1993 (Chuang et al., 1993). Commercially available macroarrays have continued to produce useful data, and should be considered before recourse to microarrays (Tao et al., 1999). The recent application of robotics to achieve high spotting densities of DNA on glass slides was innovative and facilitates the construction of microarrays containing up to 50000 genes on a single microscope slide (DeRisi et al., 1996; Shalon et al., 1996). This allows a single hybridization to be performed against multiple replicates of a single bacterial genome, or against copies of several unrelated genomes on a single glass slide. The development that has facilitated the reproducible comparison of gene expression between two samples, and hence between experiments, is dual fluorescent labelling (Schena et al., 1995). Simultaneous hybridization of two cDNA populations labelled with the fluorescent dyes Cy3 and Cy5 allows accurate assessment of relative levels of gene expression, which is unaffected by hybridization variability or the differences between individual microarrays which can complicate macroarray experiments.

\section{Microarrays as a research tool}

Microarrays allow us to produce a 'gene expression profile' or 'signature' for a particular organism under certain environmental conditions. Since the first report

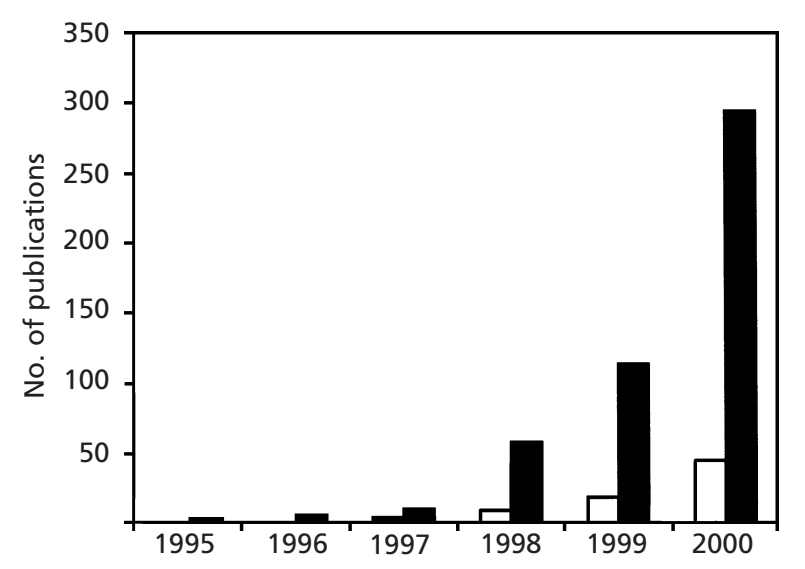

Fig. 1. The dramatic increase in the number of publications involving DNA microarrays. $\square$, All microarray papers; $\square$, microbial microarray papers only. 
Table 1. Applications of microarray technology to microbiological research

\begin{tabular}{|c|c|c|c|}
\hline Application & Organism & Type of array* & Reference \\
\hline \multicolumn{4}{|l|}{ Response to stress/environmental change } \\
\hline Diauxic shift & Sacch. cerevisiae & cDNA glass slides & DeRisi et al. (1997) \\
\hline Growth in minimal/rich media & Sacch. cerevisiae & HDA & Wodicka et al. (1997) \\
\hline $\begin{array}{l}\text { Heat shock, cold shock, growth with } \\
\text { galactose/glucose }\end{array}$ & Sacch. cerevisiae & cDNA glass slides & Lashkari et al. (1997) \\
\hline Effect of DNA-damaging agents & Sacch. cerevisiae & HDA & Jelinsky \& Samson (1999) \\
\hline Growth in minimal/rich media & E. coli & cDNA membranes & Tao et al. (1999) \\
\hline Growth in minimal/rich media & E. coli & cDNA glass slides & Wei et al. (2001) \\
\hline IPTG, heat shock & E. coli & $\begin{array}{l}\text { cDNA membranes and } \\
\text { glass slides }\end{array}$ & $\begin{array}{l}\text { Richmond et al. (1999); Wei et } \\
\text { al. (2001) }\end{array}$ \\
\hline Aerobic/anaerobic growth & Sacch. cerevisiae & HDA & ter Linde et al. (1999) \\
\hline Aerobic/anaerobic growth & B. subtilis & cDNA glass slides & Ye et al. (2000) \\
\hline Osmotic stress & Sacch. cerevisiae & cDNA glass slides & Posas et al. (2000) \\
\hline Growth in different carbon sources & E. coli & cDNA glass slides & Oh \& Liao $(2000)$ \\
\hline Metal-ion tolerance & E. coli & cDNA membranes & Brocklehurst \& Morby (2000) \\
\hline Quorum sensing & $\begin{array}{c}\text { Streptococcus } \\
\text { pneumoniae }\end{array}$ & HDA & de Saizieu et al. (2000) \\
\hline $\begin{array}{l}\text { Response to changes that affect tryptophan } \\
\text { metabolism }\end{array}$ & E. coli & cDNA glass slides & Khodursky et al. (2000a) \\
\hline \multicolumn{4}{|l|}{ Cell-cycle-associated gene expression } \\
\hline $\begin{array}{l}\text { Transcriptional programme of sporulation in } \\
\text { yeast }\end{array}$ & Sacch. cerevisiae & cDNA glass slides & $\begin{array}{l}\text { Chu et al. (1998); Primig et al. } \\
(2000)\end{array}$ \\
\hline Identification of cell-cycle-regulated genes & Sacch. cerevisiae & cDNA glass slides & Spellman et al. (1998) \\
\hline Analysis of mitotic cell cycle & Sacch. cerevisiae & HDA & Cho et al. (1998) \\
\hline $\begin{array}{l}\text { Transcriptional changes during competence } \\
\text { development }\end{array}$ & Strep. pneumoniae & cDNA membranes & Rimini et al. (2000) \\
\hline Identification of cell-cycle-regulated genes & C. crescentus & cDNA glass slides & Laub et al. (2000) \\
\hline \multicolumn{4}{|l|}{ Dissection of regulatory circuitry } \\
\hline $\begin{array}{l}\text { Effects of mutation in RNA polymerase II } \\
\text { components, determination of mRNA } \\
\text { stability }\end{array}$ & Sacch. cerevisiae & HDA & Holstege et al. (1998) \\
\hline $\begin{array}{l}\text { Promotor sequence analysis of coexpressed } \\
\text { genes }\end{array}$ & Sacch. cerevisiae & 'In silico biology' & $\begin{array}{l}\text { Wolfsberg et al. (1999); Zhang } \\
\text { (1999) }\end{array}$ \\
\hline $\begin{array}{l}\text { Effects of nucleosome depletion on gene } \\
\text { expression }\end{array}$ & Sacch. cerevisiae & HDA & Wyrick et al. (1999) \\
\hline Effects of gene dosage & Sacch. cerevisiae & HDA & $\begin{array}{l}\text { Galitski et al. (1999); Giaever } \\
\text { et al. (1999) }\end{array}$ \\
\hline Effects of gene dosage & Sacch. cerevisiae & cDNA glass slides & Hughes et al. (2000b) \\
\hline $\begin{array}{l}\text { Snf/Swi protein complex mutants and } \\
\text { nucleosome structure }\end{array}$ & Sacch. cerevisiae & cDNA glass slides & Sudarsanam et al. (2000) \\
\hline $\begin{array}{l}p d r 1 p / p d r 3 p \text { mutants (transcriptional } \\
\text { activators involved in pleiotropic drug } \\
\text { resistance) }\end{array}$ & Sacch. cerevisiae & cDNA glass slides & DeRisi et al. (2000) \\
\hline Regulation of iron uptake & Sacch. cerevisiae & cDNA glass slides & Yun et al. (2000) \\
\hline $\begin{array}{l}\text { marA mutants (transcriptional activator } \\
\text { involved in drug resistance) }\end{array}$ & E. coli & cDNA membranes & Barbosa \& Levy (2000) \\
\hline $\begin{array}{l}\text { Characterization of the Fap1p zinc-sensitive } \\
\text { regulon }\end{array}$ & Sacch. cerevisiae & cDNA glass slides & Lyons et al. (2000) \\
\hline Regulation of glycolytic enzyme genes & Sacch. cerevisiae & cDNA membranes & Lopez \& Baker (2000) \\
\hline Identification of copper regulon & Sacch. cerevisiae & cDNA glass slides & Gross et al. (2000) \\
\hline Chromosomal position and gene expression & Sacch. cerevisiae & In silico & Cohen et al. (2000a) \\
\hline Characterization of IHF regulon & E. coli & cDNA membranes & Arfin et al. (2000) \\
\hline Function of histone deacetylase & Sacch. cerevisiae & cDNA glass slides & Bernstein et al. (2000) \\
\hline Translational regulation & Sacch. cerevisiae & cDNA glass slides & Kuhn et al. (2001) \\
\hline
\end{tabular}


Table 1 (cont.)

\begin{tabular}{|c|c|c|c|}
\hline Application & Organism & Type of array* & Reference \\
\hline \multicolumn{4}{|l|}{ Genomotyping } \\
\hline Detection of point mutation polymorphism & M. tuberculosis & HDA & Gingeras et al. (1998) \\
\hline \multirow[t]{2}{*}{ Detection of gene deletions/insertions } & E. coli & cDNA membranes & Riehle et al. (2001) \\
\hline & $\begin{array}{l}\text { M. tuberculosis/ } \\
\text { M. bovis }\end{array}$ & cDNA glass slides & Behr et al. (1999) \\
\hline \multirow[t]{2}{*}{ Strain comparison } & Sacch. cerevisiae & HAD & Winzeler et al. (1999a) \\
\hline & Helicobacter pylori & cDNA glass slides & Salama et al. (2000) \\
\hline $\begin{array}{l}\text { Species identification and detection of point } \\
\text { mutations in } r p o B\end{array}$ & M. tuberculosis & HDA & Troesch et al. (1999) \\
\hline \multicolumn{4}{|l|}{ Drug target characterization/identification } \\
\hline Kinase inhibitors & Sacch. cerevisiae & HDA & Gray et al. (1998) \\
\hline Effects of immunosuppressant FK506 & Sacch. cerevisiae & cDNA glass slides & Marton et al. (1998) \\
\hline Isoniazid & M. tuberculosis & cDNA glass slides & Wilson et al. (1999) \\
\hline $\begin{array}{l}\text { Effect of amino acid biosynthesis inhibitor } \\
\text { sulfometuron methyl }\end{array}$ & Sacch. cerevisiae & cDNA glass slides & Jia et al. (2000) \\
\hline Antifungal agents & Sacch. cerevisiae & HDA & Bammert \& Fostel (2000) \\
\hline \multicolumn{4}{|l|}{ Cellular response to bacterial infection } \\
\hline $\begin{array}{l}\text { Infection of monocytes (THP-1) with Listeria } \\
\text { monocytogenes }\end{array}$ & Human & $\begin{array}{l}\text { HDA, cDNA } \\
\text { membranes, cDNA } \\
\text { colony filters }\end{array}$ & Cohen et al. (2000b) \\
\hline $\begin{array}{l}\text { Infection of intestinal epithelial cells (HT-29 } \\
\text { and T84) with Salmonella enterica }\end{array}$ & Human & cDNA membranes & Eckmann et al. (2000) \\
\hline $\begin{array}{l}\text { Infection of macrophages cells (RAW 264.7) } \\
\text { with Sal. typhimurium }\end{array}$ & Mouse & cDNA membranes & Rosenberger et al. (2000) \\
\hline $\begin{array}{l}\text { Infection of epithelial cells (lung carcinoma } \\
\text { A549 cell line) with Pseudomonas } \\
\text { aeruginosa }\end{array}$ & Human & cDNA glass slides & Ichikawa et al. (2000) \\
\hline $\begin{array}{l}\text { Infection of intestinal epithelial cells (HeLa } \\
\text { 229) with Chlamydia trachomatis }\end{array}$ & Human & cDNA membranes & Dessus-Babus et al. (2000) \\
\hline $\begin{array}{l}\text { Infection of bronchial epithelial cells (BEAS- } \\
\text { 2B) with Bordetella pertussis }\end{array}$ & Human & HDA & Belcher et al. (2000) \\
\hline $\begin{array}{l}\text { In vivo effects of a commensal bacterium on } \\
\text { the gene expression of the ileal epithelium }\end{array}$ & Mouse & HDA & Hooper et al. (2001) \\
\hline \multicolumn{4}{|l|}{ Others } \\
\hline Identification of genetic markers & Sacch. cerevisiae & HDA & Winzeler et al. (1998) \\
\hline Characterization of adaptive evolution & Sacch. cerevisiae & cDNA glass slides & Ferea et al. (1999) \\
\hline RNA surveillance & Sacch. cerevisiae & HDA & Lelivelt \& Culbertson (1999) \\
\hline Prediction of protein subcellular localization & Sacch. cerevisiae & cDNA glass slides & Diehn et al. (2000) \\
\hline $\begin{array}{l}\text { Analysis of topoisomerase function at } \\
\text { replication forks }\end{array}$ & E. coli & cDNA glass slides & Khodursky et al. (2000b) \\
\hline $\begin{array}{l}\text { Role of RNA polymerase II subunit Rpb9 on } \\
\text { transcription elongation }\end{array}$ & Sacch. cerevisiae & cDNA glass slides & Hemming et al. (2000) \\
\hline $\begin{array}{l}\text { Prediction of gene function by comparing } \\
\text { expression profiles of deletion mutants }\end{array}$ & Sacch. cerevisiae & cDNA glass slides & Hughes et al. (2000a) \\
\hline $\begin{array}{l}\text { Genome-wide location of DNA-binding } \\
\text { proteins }\end{array}$ & Sacch. cerevisiae & cDNA glass slides & $\begin{array}{l}\text { Ren et al. (2000); Vishwanath } \\
\text { et al. (2001) }\end{array}$ \\
\hline
\end{tabular}

*HDA, high-density oligonucleotide array.

of DNA microarray technology in 1995 (Schena et al., 1995; DeRisi et al., 1996; Lockhart et al., 1996) the potential of DNA microarrays has certainly captured the imagination of biologists worldwide. Naturally, we welcome the ability to monitor global gene expression in a single experiment rather than relying on the 'one gene
$=$ one postdoc' approach to eventually elucidate the function of all bacterial genes. However, there has also been a concern that this genome-wide approach might signal a move towards 'non-hypothesis-driven' or 'datadriven' science (Brent, 1999), a term that has been used rather pejoratively. It is clear that scientific inference 
uses a combination of deductive and inductive reasoning (Kell \& King, 2000). Functional genomics allows us to make new and unexpected links between the function of unrelated and hitherto uncharacterized genes, and suggest hypotheses, which must subsequently be tested by more traditional methods of molecular genetics and biochemistry (Hughes et al., 2000a). An example lies with the increasing numbers of proteins which have unexpectedly been found to have dual cellular functions, such as enolase and aconitases: in addition to being a glycolytic enzyme enolase is also a vital constituent of the RNA degradosome (Py et al., 1996), and aconitases, besides their catalytic role in the TCA cycle, have been shown to act as a post-transcriptional regulator by binding mRNA (Tang \& Guest, 1999). Genomic-scale research may be termed 'non-hypothesis-driven' science, but we suggest it should be viewed positively as it is likely to reveal the function of many genes which have been missed by more conventional approaches. The need for this is apparent when considering the genome sequence of E. coli, which still contains 1632 (38\%) FUN genes (of unknown function; Hinton, 1997), which remain to be functionally characterized (Nelson et al., 2000). The role of FUN genes will not be discovered without the application of functional genomic technologies combined with creative experiments.

The explosive growth in the numbers of reviews discussing microarray technology has now been followed by many papers describing results obtained from gene expression microarray profiling (Fig. 1). Genomic and post-genomic approaches are likely to revolutionize our ability to understand how micro-organisms act, both in the laboratory and in the real world. But what effect has this new approach had on molecular microbiologists in general, and what difference is it likely to make in the future?

The answer depends on one's field of research. Yeast researchers have already embraced microarrays as a useful and productive tool, as exemplified by $60 \%$ of the publications in Table 1. In other areas of microbiology, the application of microarray technology to bacteria has been slower. E. coli, Mycobacterium tuberculosis and other bacteria were the subject of just $37 \%$ of the microbial papers involving microarrays. The slow application of microarrays to academic bacterial research probably reflects the complex nature of this technology. Many pharmaceutical and biotechnology companies are successfully using bacterial microarrays to drive programmes of novel drug development, and this industrial experience suggests that technical problems will not be a barrier. We hope that work in our own and other laboratories worldwide will soon produce a raft of informative data concerning bacterial gene expression.

\section{Microbial gene expression profiling}

Microarrays have already been used to perform highquality experiments, which have improved our understanding of microbial environmental responses and (a)

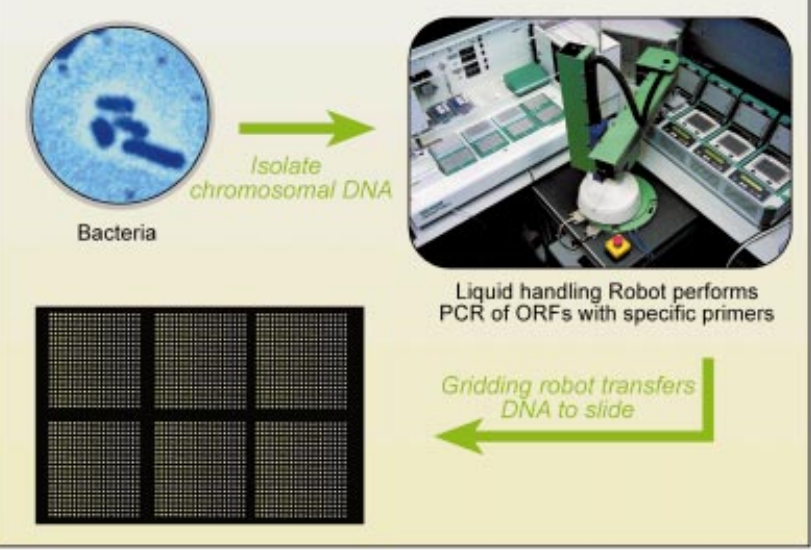

(b)

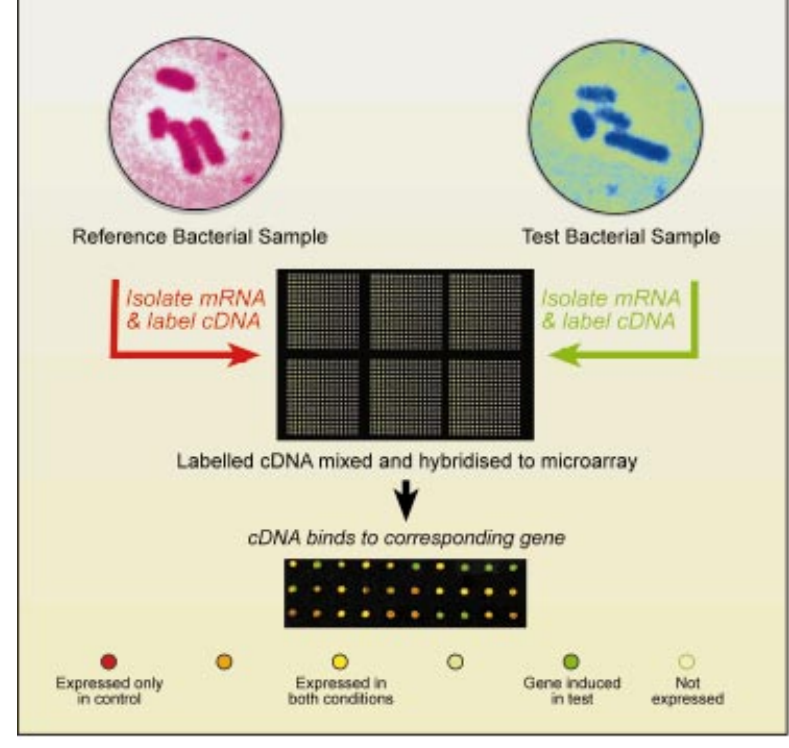

Fig. 2. Making (a) and using (b) DNA microarrays for gene expression profiling. CDNA labelling was performed using the indirect labelling method (http://www.microarrays.org).

global gene expression (Fig. 2; Table 1) and the concept of the 'global transcriptional response' as a detailed molecular phenotype is now gaining acceptance (Hughes et al., 2000a). The first global transcriptional profile was obtained at the resolution of individual genes for Saccharomyces cerevisiae; Pat Brown's group did this with gene-specific microarrays (DeRisi et al., 1997; Lashkari et al., 1997) and Affymetrix utilized oligonucleotide 'gene chips' (Wodicka et al., 1997). Eighteen months later, the first microarrays involving the whole genome of two prokaryotes were described: $M$. $t \boldsymbol{t u}$ berculosis (Behr et al., 1999) and E. coli (Richmond et al., 1999; Tao et al., 1999). As genome sequencing projects are being completed and new applications of microarrays are being developed, the potential of microarray analysis are being rapidly applied to other micro-organisms (Table 1). It is not always appreciated 
that a complete genome sequence is not essential for a microarray project. Interesting results can be obtained from microarrays assembled from partial genome data, or from an uncharacterized gene library, where spots of interest are sequenced once their expression profile has been determined (Pennisi, 2000).

Yeast has been the micro-organism of choice for many research groups to analyse cell-cycle-associated gene expression and the effects of various environmental changes, such as osmotic shock, temperature shock, presence of DNA-damaging agents and growth in minimal or rich media (Table 1). The new level of analysis provided by whole-genome expression profiling has revealed the complexity of the cellular response to major changes in metabolism, exemplified by work on yeast diauxic shift (DeRisi et al., 1997). The expression levels of 1840 genes ( $30 \%$ of a total of 6116 genes tested) were found to be affected by the transition from anaerobic to aerobic growth. Similar complexity of gene expression in the transcriptional programme was reported for yeast going through the mitotic cell cycle (Cho et al., 1998; Spellman et al., 1998) or sporulation (Chu et al., 1998). Many of the responsive genes that were identified had previously been designated as FUN. To understand the large amount of data created by microarrays, Mike Eisen developed a computer program to cluster genes according to their expression profiles (Eisen et al., 1998). Based on the important observation that functionally related genes show similar patterns of expression, identification of well-characterized genes that are co-expressed with FUN genes can give important clues towards function. Using this tool, Chu et al. (1998) defined seven sequential temporal classes of genes induced during yeast sporulation.

One of the most impressive examples of the use of microarrays for bacterial research has been provided by recent work on Caulobacter crescentus (Laub et al., 2000). The definition of the cell cycle of C. crescentus by microarray analysis revealed that 572 of 2966 genes $(19 \cdot 3 \%)$ were cell-cycle-dependent. Not only were a number of classes of cell-cycle-induced genes identified, but also the proportion dependent upon the global cell cycle regulator CtrA was recognized for the first time. This study led to recognition of the role of 11 novel sensor kinases and 5 new sigma factors. The identification of cascades of gene expression during the Caulobacter cell cycle is an important landmark for bacterial research. We look forward to similar studies describing gene expression cascades during sporulation of Bacillus subtilis, and during E. coli cell division.

\section{Definition of entire regulons}

Because cell cycle and environmental changes are multifactorial, involving important metabolic changes, it is difficult to unravel the role played by specific global gene regulators. The definition of important regulons by the use of appropriate regulatory mutants provides the framework for a better understanding of complex cellular responses. This approach has led to the global characterization of the IHF and MarA regulons of $E$. coli (Arfin et al., 2000; Barbosa \& Levy, 2000), but does not distinguish between direct and indirect effects of regulatory mutations. More recently, DNA microarrays have been used to combine gene expression profile analysis with the localization of binding sites for DNAbinding proteins on the yeast genome. This approach involved the formaldehyde cross-linking of proteins to the DNA, followed by a modified chromatin precipitation procedure. After cell disruption, proteins were immunoprecipitated to enrich for DNA fragments containing DNA-binding sites. The enriched DNA was then amplified, labelled and hybridized to a microarray containing all yeast intergenic regions. This new approach permitted the identification of genes which were directly controlled by the regulatory proteins Gal4 and Ste12 (Ren et al., 2000).

\section{Analysis of gene expression in vivo}

The use of microarrays for the study of bacterial infection at the level of gene expression is in its infancy (Cummings \& Relman, 2000; Hautefort \& Hinton, 2000). We require improved technology for in vivo study of infection, both from the host's and the pathogen's point of view. Bacterial mRNA is less stable than eukaryotic mRNA, and is generally not polyadenylated, complicating mRNA purification (Sarkar, 1996). This does not cause problems for in vitro analyses, but does complicate the isolation of sufficient, good-quality bacterial mRNA from complex environments such as mammalian tissue. Advances have recently been made in applying the linear RNA amplification method (Eberwine et al., 1992), which has been used to extract sufficient eukaryotic mRNA for microarray analyses from small amounts of mammalian tissue (Lockhart et al., 1996; Luo et al., 1999; Wang et al., 2000). The successful application of this linear RNA amplification approach to polycistronic and non-polyadenylated bacterial mRNA remains to be demonstrated. An alternative way to decrease the amount of bacterial RNA required for the labelling of mRNA involves the new concept of genome-specific primers. Thirty-seven genome-directed primers (GDPs) were predicted to be sufficient to prime all genes in the M. tuberculosis genome, and were used to label mycobacterial RNA (Talaat et al., 2000). The cDNA probes generated by GDPs showed improved sensitivity and specificity when compared with probes obtained by random priming, and allowed a degree of selective amplification of mycobacterial RNA from a mix containing mammalian RNA.

Mammalian gene microarrays have recently been used to study host-pathogen interactions from the viewpoint of the host, by identifying gene expression patterns induced by the presence of a pathogen (Manger \& Relman, 2000). Several in vitro studies have explored the effects of infection on the mRNA expression profile of human cells (Table 1). The effects of Listeria monocytogenes (Cohen et al., 2000b), Salmonella enterica (Eckmann et al., 2000) and Salmonella typhimurium 
(Rosenberger et al., 2000) have recently been reviewed by Cummings \& Relman (2000). Briefly, these studies reveal a specific host response, which is modulated by different host factors (Rosenberger et al., 2000). Other groups are using a more complex approach by comparison of the human cellular transcriptional signatures of pathogenic strains carrying well-defined mutations to get a more detailed view of the mechanisms underlying pathogen clearance (Manger \& Relman, 2000).

\section{Genomotyping and microbial evolution}

Phylogenetic classification based on rRNA/rDNA and signature sequences is usually able to provide an accurate classification of micro-organisms above the species level (Gupta, 2000). However, it has become evident that lateral gene transfer is an important mechanism of evolution for prokaryotes, complicating phylogenetic analysis based on a small number of genes. Differences can be considerable between closely related bacterial pathogens: certain serovars of $S$. enterica contain more than a megabase of sequence information than others (Ochman et al., 2000). Preliminary analysis suggests that more than 700 ORFs are present in Salmonella typhi and not in Sal. typhimurium (P. O'Gaora, personal communication). Acquisition of new DNA is clearly an important mechanism for the adaptation of bacteria to new ecological niches, as shown by the example of the acquisition of pathogenicity islands, which encode virulence factors and were probably acquired at different times (Groisman \& Ochman, 1997). Whole-genome based methods are thus required to determine the repertoire of virulence genes found in bacterial pathogens. Strain comparison by hybridizing genomic DNA to microarrays (genomotyping) is a more realistic approach than the whole-genome sequencing of dozens of strains. Gene-specific microarrays have been used to compare the entire genome of a Mycobacterium bovis vaccine strain with the closely related $M$. $t u$ berculosis $\mathrm{H} 37 \mathrm{Rv}$, resulting in a 'gene-specific fingerprint' at a resolution of approximately $2 \mathrm{~kb}$ (Behr et al., 1999). Alternatively, mutant alleles or single nucleotide polymorphisms (SNPs) can be detected with highdensity oligonucleotide microarrays, which carry much shorter targets (typically about $25 \mathrm{nt}$ on Affymetrix gene chips). A single nucleotide difference between target and probe can be sufficient to prevent hybridization, and has been used to identify 3000 polymorphisms between two strains of Sacch. cerevisiae. These polymorphisms were used as markers to map five uncharacterized loci to within 11-64 kb (Winzeler et al., 1998). Complete characterization of SNPs can be achieved for each base of a sequence of interest by using a set of four oligonucleotides, one oligonucleotide corresponding to the wild-type and the remaining oligonucleotides to the three possible mutations (Lemieux et al., 1998). Oligonucleotide-chip-based mutation analysis is limited by a lack of sensitivity for mutations in regions with high local A/T or G/C content or for small frameshift mutations (Favis et al., 2000). Nevertheless, this method promises to be extremely powerful as a diagnostic tool, as demonstrated by the identification of mutations in a 705 bp region of the $r p o B$ gene, which caused rifampicin resistance in 44 clinical isolates of $M$. tuberculosis (Gingeras et al., 1998).

\section{Industrial applications of microarrays}

Gene expression profiling is being used to determine the effects of antibiotics, agrochemicals and pharmaceutical products on different organisms, and is being used in the search for new antimicrobials. Strategies for drug-target validation and the identification of secondary effects have been described previously (Rosamond \& Allsop, 2000). Following determination of the 'expression signature' of a wide range of compounds, the prediction of the mode of action of a novel compound becomes possible, simply on the basis of analysis of the transcriptional changes made by the drug. Large biotech companies are already using this approach to obtain cost-effective information, which avoids large-scale mode-of-action studies.

\section{Microarray data analysis}

Microarrays provide huge amounts of data. This can be an advantage and a disadvantage; the potential of genome-scale information is incredible, but often the results of microarray analyses have been limited to the production of a catalogue of the induction or repression ratios of particular genes. This restricted approach fails to exploit the true value of microarray data. To obtain interesting and reliable hypotheses, and hence results, good mathematical and statistical tools are needed for the intelligent interrogation, or 'mining' of microarray data. Consensus must be reached on the level of differential gene expression that is truly significant, and similar approaches must be used by the worldwide community. This will be complicated by a recent analysis of global gene expression in E. coli, which concluded that there was "little correlation between the "fold difference" and the accuracy of differential gene expression levels'. Thus, the significance of differential gene expression measurements cannot be assessed simply by considering the magnitude of the difference between two experimental conditions (Arfin et al., 2000). For a single microarray experiment involving 5000 measurements, it is predicted that 250 false positives could arise from a Gaussian distribution of data points, emphasizing the importance of experimental replication and careful assessment of statistical significance (Arfin et al., 2000). To assess issues such as the number of assays required, the significance of changes in expression levels or within a cluster analysis will be essential (Zweiger, 1999). Fortunately, bioinformatic tools are being developed at great speed (Ochman et al., 2000). As well as extracting all we can from microarray data, we also need to be able to directly compare experiments within our research community. Since whole-genome transcriptional responses are very complex, all source of noise must be minimized, and good standardization procedures must be applied in 
terms of experimental design, the description of results and the format for data storage (Aach et al., 2000). There is a strong argument for the use of universal controls for particular microarrays. For example, the proposed use of genomic DNA as a reference for all gene expression studies performed by members of the Sal. typhimurium microarray community should facilitate rapid exchange of meaningful data between laboratories.

A further step towards the prediction of gene function has been made by combining the high-throughput production of data provided by microarrays with a rigorous statistical analysis. Hughes et al. (2000a) have reported a large-scale approach that is intended to avoid problems of biological noise, and to build up a reference database or 'compendium' of patterns of gene expression profiles corresponding to 300 different mutations and chemical treatments in Sacch. cerevisiae. Two-dimensional hierarchical clustering of the obtained expression profiles identified several large groups of coregulated genes. Mutations in genes having similar known functions gave rise to similar profiles, which clustered together, giving an experimental basis for gene function prediction. This tactic has allowed small but coordinated differential gene expression levels to be observed across many different conditions, and to be related to gene function.

In the excitement of pursuing gene expression profiling for entire organisms, we must not lose sight of the fact that mRNA is only one intermediate between DNA and protein. Post-transcriptional and post-translational controls also play a major role in modulating protein expression. Transcriptional analysis may generate hypotheses, but more traditional molecular biological and proteomic approaches are still required to test these hypotheses.

The utility of microarrays now extends to the study of translational initiation. Kuhn et al. (2001) analysed translational regulation of specific mRNAs in yeast. Polysomal fractionation was used in conjunction with microarrays to study changes in translational initiation during diauxic shift. Although overall mRNA translation decreased, the authors identified one group of mRNA species (representing 610 out of 6275 genes examined) whose level of translational initiation was less affected by the change in carbon source. This group corresponded to the genes upregulated on diauxic shift, emphasizing the importance to the cell of mechanisms that ensure the translation of newly expressed genes.

\section{Reliability of microarray data}

High-level mathematics has taught us that it is important to prevent the introduction of systematic bias when working with large numbers of variables. This concept holds true for microarray data analysis. Errors may be introduced at many points between the production of microarrays and the analysis of hybridization signals. Two critical steps that may strongly affect the results are the isolation of RNA and the generation of fluorescently labelled probes. RNA purification is inherently more difficult for bacterial than mammalian systems. The absence of polyadenylated mRNA means that cDNA labelling must be performed with total RNA, only approximately $3 \%$ of which is mRNA. Furthermore, bacterial mRNA is much less stable than eukaryotic mRNA. The half-life of mRNA molecules in E. coli can be as short as $30 \mathrm{~s}$ (Carpousis et al., 1999). Since differential mRNA instability is an important mechanism in the control of gene expression, great care must be taken to obtain quality RNA that has not been degraded. The rapid stabilization of RNA by addition of chaotropic agents such as guanidinium isothiocyanate is one important tool (Cox, 1968). Alternative commercial products such as RNALater (Ambion) perform a similar function. The initial stabilization of bacterial RNA is critical; otherwise one is in danger of studying coldshock genes induced during centrifugation of bacteria at $4{ }^{\circ} \mathrm{C}$ prior to RNA extraction! The cDNA synthesis step is also critical because the cDNA probe must reflect a representative population of labelled mRNA species. It has recently been shown that the reverse transcription of E. coli RNA using a pool of primers specific to the 3' regions of all mRNA molecules had a significant underrepresentation of about $30 \%$ of mRNAs when compared to the use of random hexamers (Arfin et al., 2000). Another problem that can be associated with labelling is that different fluorescent dyes do not have the same incorporation rate during labelling. This can be controlled by performing 'dye swap' experiments (Wei et al., 2001), but we recommend the 'indirect' labelling approach to avoid this problem (http:// www.microarrays.org).

We have described some of the technical problems commonly encountered with microarrays. It is important to remember that the use of microarrays for gene expression profiling is a recent development, and some aspects of the approach are not completely understood. Therefore, important results obtained with microarrays must be confirmed with other techniques, such as realtime quantitative PCR or Northern blotting, until microarray-based methodologies are completely validated.

\section{To build or to buy, that is the question}

Many laboratories and research centres are considering whether to invest in microarray technology or to obtain pre-printed microarrays from commercial sources. A number of macroarrays (membrane-based arrays) and microarrays (glass slides) of interest to microbiologists are already available. Currently, the variety of arrayed microbial genomes on the market is restricted to relatively few organisms (Table 2), though on-going genome sequencing projects will rapidly expand this selection in the near future. However, current pricing is set at a high level (between $£ 500$ and $£ 1000$ per microarray), reflecting a lack of competition.

A common misconception is that gene expression profiling experiments will only require a small number 
Table 2. Commercial 'pre-printed' microarrays (currently or soon to be available)

\begin{tabular}{|ll|}
\hline Micro-organism & \multicolumn{1}{c|}{ Supplier } \\
\hline Bacillus subtilis & Sigma-Genosys, Eurogentech \\
Candida albicans & Eurogentech, Incyte \\
Escherichia coli & Sigma-Genosys, TaKaRa Biomedicals \\
Helicobacter pylori & Eurogentech \\
Neisseria meningitidis & Eurogentech \\
Saccharomyces cerevisiae & Corning, Eurogentech, Operon \\
Staphylococcus aureus & Incyte \\
Streptococcus pneumoniae & Eurogentech \\
\hline
\end{tabular}

of microarrays. Researchers must expect to use a significant number of microarrays to produce reliable data. Unfortunately, unlike radioactively labelled macroarrays, fluorescently labelled microarrays cannot be reused. A typical microarray experiment involving four time points performed in triplicate will require 12 microarrays for a single experiment, i.e. approximately $£ 6000$ at current prices plus the cost of labelling consumables. The majority of papers that have used microarray technology in the past year have described results from single experiments, without replicates or any indication of statistical significance. Such data require the 'suspension of disbelief' by the reader, and are unlikely to be acceptable in the future.

The scale of replication required to yield significant data could prove to be a significant barrier to the widespread application of microarray technology. And it is not yet possible for every medium-sized lab to design and print its own microarray slides. 'In-house' microarray technology is still expensive (especially at the level of consumables) and labour-intensive. The equipment for making and analysing microarrays is readily available, at a price. But fierce competition is pushing some companies to release machines before they are completely optimized. We would argue that it is worthwhile to rely on the robust homemade Stanford technology, which is responsible for the majority of microarray publications to date (Thompson et al., 2001). The significant investment now being made in genomic and post-genomic centres throughout Europe should allow researchers at all levels to pursue functional genomic approaches, either independently or through collaboration, without needing to set-up 'in-house' facilities. Clearly, financial constraints can be overcome: Oh \& Liao (2000) successfully used a small 'subarray' of 111 $E$. coli genes involved in central metabolism to investigate metabolic flux.

\section{Caveat emptor!}

We must emphasize that the use of microarrays for molecular microbiology is still not straightforward. The generation of reliable data requires an extremely rigorous approach, both at the technical and the microbiological levels. Appropriate experimental design is also essential. Simple basic errors, such as choice of the wrong media or the stage of the growth phase used to compare mutant and wild-type strains, can dramatically affect gene expression! Changes in gene expression can be very transient. A $10 \mathrm{~min}$ exposure of yeast to $0.4 \mathrm{M}$ $\mathrm{NaCl}$ resulted in the induction of 1300 genes, whereas only 172 induced genes were detected after $20 \mathrm{~min}$ (Posas et al., 2000). Learning to use microarrays often takes months rather than weeks, and requires the support of an experienced laboratory. Microarray experiments should not be entered into lightly!

\section{The future}

Genomotyping should revolutionize our ability to distinguish bacteria. The combination of other 'chip technologies' with genomotyping has already produced a prototype capable of separating E. coli from blood and performing subsequent microarray analysis (Cheng et al., 1998). Whether or not this will prove applicable to the diagnostics market depends upon cost considerations, and whether the technology can be made sufficiently robust to perform in the environment of a microbiology laboratory. We should remember that PCR promised to be a sensitive diagnostic tool, but has not led to many validated diagnostic approaches.

A significant area that needs to be investigated is the utility of microarrays for analysis of mixed bacterial communities. The application of gene expression profiling or genomotyping to obtain information about individual species within a natural community would prove invaluable for microbial ecology and for microbial systematics alike. Assuming that appropriate hybridization stringencies are employed, and given a sufficient microbial diversity within the population of interest, there is no theoretical reason for this approach to fail.

Microarrays can also be used to gain clues to gene function through looking at knockout mutants, particularly of predicted regulatory genes. This approach has already been successfully used by Winzeler et al. $(1999 \mathrm{~b})$ to follow the growth of pools of 500 yeast knockout mutants under various environmental conditions. Each mutant was tagged with a unique oligonucleotide sequence (a 'molecular barcode') that was detected by hybridization to a custom-built microarray to determine growth conditions when certain mutants 
were unable to grow. This methodology combined with a massive parallel analysis of mapped mutants (RossMacdonald et al., 1999; Spradling et al., 1999) offers a rapid route to determining the function of the FUN genes found in every microbial genome (Hinton, 1997).

The application of microbial gene expression profiling is only limited by our imagination! Bacteria have been used for decades as sensitive biosensors for mutagenicity (Maron \& Ames, 1983), and this approach has recently been brought up to date. E. coli has been used to determine the effects of microwave radiation produced by mobile telephones. Macroarray analysis demonstrated that 13 genes were induced by a $2 \mathrm{~h}$ exposure to a commercial mobile telephone (A. Morby, personal communication). As we integrate the power of microarray analyses with our particular research interests, more creative applications are bound to arise.

We are moving from the period of genomics towards the post-genomic future and we are entering what is arguably the most exciting period in the history of microbiology. At last we have the potential to ask questions at a relevant scale, that of the whole genome and hence the whole organism. We are optimistic that swift progress will be made as we learn to implement microarray technology more effectively, and we look forward to the time when innovative ideas can be tested extremely quickly.

\section{References}

Aach, J., Rindone, W. \& Church, G. M. (2000). Systematic management and analysis of yeast gene expression data. Genome Res 10, 431-445.

Alwine, J. C., Kemp, D. J. \& Stark, G. R. (1977). Method for detection of specific RNAs in agarose gels by transfer to diazobenzyloxymethyl-paper and hybridization with DNA probes. Proc Natl Acad Sci US A 74, 5350-5354.

Alwine, J. C., Kemp, D. J., Parker, B. A., Reiser, J., Renart, J., Stark, G. R. \& Wahl, G. M. (1979). Detection of specific RNAs or specific fragments of DNA by fractionation in gels and transfer to diazobenzyloxymethyl paper. Methods Enzymol 68, 220-242.

Arfin, S. M., Long, A. D., Ito, E. T., Tolleri, L., Riehle, M. M., Paegle, E. S. \& Hatfield, G. W. (2000). Global gene expression profiling in Escherichia coli K12. The effects of integration host factors. J Biol Chem 275, 29672-29684.

Bammert, G. F. \& Fostel, J. M. (2000). Genome-wide expression patterns in Saccharomyces cerevisiae: comparison of drug treatments and genetic alterations affecting biosynthesis of ergosterol. Antimicrob Agents Chemother 44, 1255-1265.

Barbosa, T. M. \& Levy, S. B. (2000). Differential expression of over 60 chromosomal genes in Escherichia coli by constitutive expression of MarA. J Bacteriol 182, 3467-3474.

Behr, M. A., Wilson, M. A., Gill, W. P., Salamon, H., Schoolnik, G. K., Rane, S. \& Small, P. M. (1999). Comparative genomics of BCG vaccines by whole-genome DNA microarray. Science 284, 1520-1523.

Belcher, C. E., Drenkow, J., Kehoe, B., Gingeras, T. R., McNamara, N., Lemjabbar, H., Basbaum, C. \& Relman, D. A. (2000). The transcriptional responses of respiratory epithelial cells to Bordetella pertussis reveal host defensive and pathogen counterdefensive strategies. Proc Natl Acad Sci US A 97, 13847-13852.
Bernstein, B. E., Tong, J. K. \& Schreiber, S. L. (2000). Genomewide studies of histone deacetylase function in yeast. Proc Natl Acad Sci U S A 97, 13708-13713.

Brent, R. (1999). Functional genomics: learning to think about gene expression data. Curr Biol 9, R338-R341.

Brocklehurst, K. R. \& Morby, A. P. (2000). Metal-ion tolerance in Escherichia coli: analysis of transcriptional profiles by gene-array technology. Microbiology 146, 2277-2282.

Carpousis, A. J., Vanzo, N. F. \& Raynal, L. C. (1999). mRNA degradation - a tale of poly(A) and multiprotein machines. Trends Genet 15, 24-28.

Cheng, J., Sheldon, E. L., Wu, L., Uribe, A., Gerrue, L. O., Carrino, J., Heller, M. J. \& O'Connell, J. P. (1998). Preparation and hybridization analysis of DNA/RNA from E. coli on microfabricated bioelectronic chips. Nature Biotechnol 16, 541-546.

Cho, R. J., Campbell, M. J., Winzeler, E. A. \& 7 other authors (1998). A genome-wide transcriptional analysis of the mitotic cell cycle. Mol Cell 2, 65-73.

Chu, S., DeRisi, J., Eisen, M., Mulholland, J., Botstein, D., Brown, P. O. \& Herskowitz, I. (1998). The transcriptional program of sporulation in budding yeast Science 282, 699-705 (and Erratum Science 282, 1421).

Chuang, S. E., Daniels, D. L. \& Blattner, F. R. (1993). Global regulation of gene expression in Escherichia coli. J Bacteriol 175, 2026-2036.

Cohen, B. A., Mitra, R. D., Hughes, J. D. \& Church, G. M. (2000a). A computational analysis of whole-genome expression data reveals chromosomal domains of gene expression. Nature Genet 26, 183-186.

Cohen, P., Bouaboula, M., Bellis, M., Baron, V., Jbilo, O., PoinotChazel, C., Galiegue, S., Hadibi, E. H. \& Casellas, P. (2000b). Monitoring cellular responses to Listeria monocytogenes with oligonucleotide arrays. J Biol Chem 275, 11181-11190.

Cox, R. A. (1968). The use of guanidinium chloride in the isolation of nucleic acids. Methods Enzymol 12, 120-129.

Cummings, C. A. \& Relman, D. A. (2000). Using DNA microarrays to study host-microbe interactions. Emerg Infect Dis 6, 513-525.

DeRisi, J., Penland, L., Brown, P. O., Bittner, M. L., Meltzer, P. S., Ray, M., Chen, Y., Su, Y. A. \& Trent, J. M. (1996). Use of a cDNA microarray to analyse gene expression patterns in human cancer. Nature Genet 14, 457-460.

DeRisi, J. L., lyer, V. R. \& Brown, P. O. (1997). Exploring the metabolic and genetic control of gene expression on a genomic scale. Science 278, 680-686.

DeRisi, J., van den Hazel, B., Marc, P., Balzi, E., Brown, P., Jacq, C. \& Goffeau, A. (2000). Genome microarray analysis of transcriptional activation in multidrug resistance yeast mutants. FEBS Lett 470, 156-160.

Dessus-Babus, S., Knight, S. T. \& Wyrick, P. B. (2000). Chlamydial infection of polarized HeLa cells induces PMN chemotaxis but the cytokine profile varies between disseminating and nondisseminating strains. Cell Microbiol 2, 317-327.

Diehn, M., Eisen, M. B., Botstein, D. \& Brown, P. O. (2000). Largescale identification of secreted and membrane-associated gene products using DNA microarrays. Nature Genet 25, 58-62.

Eberwine, J., Yeh, H., Miyashiro, K., Cao, Y., Nair, S., Finnell, R., Zettel, M. \& Coleman, P. (1992). Analysis of gene expression in single live neurons. Proc Natl Acad Sci U S A 89, 3010-3014.

Eckmann, L., Smith, J. R., Housley, M. P., Dwinell, M. B. \& Kagnoff, M. F. (2000). Analysis by high density cDNA arrays of altered gene expression in human intestinal epithelial cells in 
response to infection with the invasive enteric bacteria Salmonella. J Biol Chem 275, 14084-14094.

Eisen, M. B., Spellman, P. T., Brown, P. O. \& Botstein, D. (1998). Cluster analysis and display of genome-wide expression patterns. Proc Natl Acad Sci US A 95, 14863-14868.

Favis, R., Day, J. P., Gerry, N. P., Phelan, C., Narod, S. \& Barany, F. (2000). Universal DNA array detection of small insertions and deletions in BRCA1 and BRCA2. Nature Biotechnol 18, 561-564.

Ferea, T. L., Botstein, D., Brown, P. O. \& Rosenzweig, R. F. (1999). Systematic changes in gene expression patterns following adaptive evolution in yeast. Proc Natl Acad Sci U S A 96, 9721-9726.

Galitski, T., Saldanha, A. J., Styles, C. A., Lander, E. S. \& Fink, G. R. (1999). Ploidy regulation of gene expression. Science 285, 251-254.

Giaever, G., Shoemaker, D. D., Jones, T. W., Liang, H., Winzeler, E. A., Astromoff, A. \& Davis, R. W. (1999). Genomic profiling of drug sensitivities via induced haploinsufficiency. Nature Genet 21, 278-283.

Gingeras, T. R., Ghandour, G., Wang, E. \& 6 other authors (1998). Simultaneous genotyping and species identification using hybridization pattern recognition analysis of generic Mycobacterium DNA arrays. Genome Res 8, 435-448.

Gray, N. S., Wodicka, L., Thunnissen, A. M. \& 10 other authors (1998). Exploiting chemical libraries, structure, and genomics in the search for kinase inhibitors. Science 281, 533-538.

Groisman, E. A. \& Ochman, H. (1997). How Salmonella became a pathogen. Trends Microbiol 5, 343-349.

Gross, C., Kelleher, M., lyer, V. R., Brown, P. O. \& Winge, D. R. (2000). Identification of the copper regulon in Saccharomyces cerevisiae by DNA microarrays. J Biol Chem 275, 32310-32316.

Gupta, R. S. (2000). The phylogeny of proteobacteria: relationships to other eubacterial phyla and eukaryotes. FEMS Microbiol Rev 24, 367-402.

Hautefort, I. \& Hinton, J. C. (2000). Measurement of bacterial gene expression in vivo. Philos Trans $R$ Soc Lond B Biol Sci 355, 601-611.

Hemming, S. A., Jansma, D. B., Macgregor, P. F., Goryachev, A., Friesen, J. D. \& Edwards, A. M. (2000). RNA polymerase II subunit Rpb9 regulates transcription elongation in vivo. $\mathrm{J} \mathrm{Biol}$ Chem 275, 35506-35511.

Hinton, J. C. (1997). The Escherichia coli genome sequence: the end of an era or the start of the FUN? Mol Microbiol 26, 417-422.

Holstege, F. C., Jennings, E. G., Wyrick, J. J., Lee, T. I., Hengartner, C. J., Green, M. R., Golub, T. R., Lander, E. S. \& Young, R. A. (1998). Dissecting the regulatory circuitry of a eukaryotic genome. Cell 95, 717-728.

Hooper, L. V., Wong, M. H., Thelin, A., Hansson, L., Falk, P. G. \& Gordon, J. I. (2001). Molecular analysis of commensal hostmicrobial relationships in the intestine. Science 291, 881-884.

Hughes, T. R., Marton, M. J., Jones, A. R. \& 19 other authors (2000a). Functional discovery via a compendium of expression profiles. Cell 102, 109-126.

Hughes, T. R., Roberts, C. J., Dai, H. \& 9 other authors (2000b). Widespread aneuploidy revealed by DNA microarray expression profiling. Nature Genet 25, 333-337.

Ichikawa, J. K., Norris, A., Bangera, M. G., Geiss, G. K., van't Wout, A. B., Bumgarner, R. E. \& Lory, S. (2000). Interaction of Pseudomonas aeruginosa with epithelial cells: identification of differentially regulated genes by expression microarray analysis of human cDNAs. Proc Natl Acad Sci US A 97, 9659-9664.

Jelinsky, S. A. \& Samson, L. D. (1999). Global response of
Saccharomyces cerevisiae to an alkylating agent. Proc Natl Acad Sci U S A 96, 1486-1491.

Jia, M. H., Larossa, R. A., Lee, J. M., Rafalski, A., Derose, E., Gonye, G. \& Xue, Z. (2000). Global expression profiling of yeast treated with an inhibitor of amino acid biosynthesis, sulfometuron methyl. Physiol Genomics 3, 83-92.

Kell, D. B. \& King, R. D. (2000). On the optimization of classes for the assignment of unidentified reading frames in functional genomics programmes: the need for machine learning. Trends Biotechnol 18, 93-98.

Khodursky, A. B., Peter, B. J., Cozzarelli, N. R., Botstein, D., Brown, P. O. \& Yanofsky, C. (2000a). DNA microarray analysis of gene expression in response to physiological and genetic changes that affect tryptophan metabolism in Escherichia coli. Proc Natl Acad Sci U S A 97, 12170-12175.

Khodursky, A. B., Peter, B. J., Schmidt, M. B., DeRisi, J., Botstein, D., Brown, P. O. \& Cozzarelli, N. R. (2000b). Analysis of topoisomerase function in bacterial replication fork movement : use of DNA microarrays. Proc Natl Acad Sci U S A 97, 9419-9424.

Kuhn, K. M., DeRisi, J. L., Brown, P. O. \& Sarnow, P. (2001). Global and specific translational regulation in the genomic response of Saccharomyces cerevisiae to a rapid transfer from a fermentable to a nonfermentable carbon source. Mol Cell Biol 21, 916-927.

Lashkari, D. A., DeRisi, J. L., McCusker, J. H., Namath, A. F., Gentile, C., Hwang, S. Y., Brown, P. O. \& Davis, R. W. (1997). Yeast microarrays for genome wide parallel genetic and gene expression analysis. Proc Natl Acad Sci U S A 94, 13057-13062.

Laub, M. T., McAdams, T. H., Feldblyum, T., Fraser, C. M. \& Shapiro, L. (2000). Global analysis of the genetic network controlling a bacterial cell cycle. Science 290, 2144-2148.

Lelivelt, M. J. \& Culbertson, M. R. (1999). Yeast Upf proteins required for RNA surveillance affect global expression of the yeast transcriptome. Mol Cell Biol 19, 6710-6719.

Lemieux, B., Aharoni, A. \& Schena, M. (1998). Overview of DNA chip technology. Mol Breed 4, 277-289.

ter Linde, J. J., Liang, H., Davis, R. W., Steensma, H. Y., van Dijken, J. P. \& Pronk, J. T. (1999). Genome-wide transcriptional analysis of aerobic and anaerobic chemostat cultures of Saccharomyces cerevisiae. J Bacteriol 181, 7409-7413.

Lockhart, D. J., Dong, H., Byrne, M. C. \& 8 other authors (1996). Expression monitoring by hybridization to high-density oligonucleotide arrays. Nature Biotechnol 14, 1675-1680.

Lopez, M. C. \& Baker, H. V. (2000). Understanding the growth phenotype of the yeast $\mathrm{gcr} 1$ mutant in terms of global genomic expression patterns. J Bacteriol 182, 4970-4978.

Luo, L., Salunga, R. C., Guo, H. \& 8 other authors (1999). Gene expression profiles of laser-captured adjacent neuronal subtypes Nat Med 5, 117-22 (and Erratum Nature Med 5, 355).

Lyons, T. J., Gasch, A. P., Gaither, L. A., Botstein, D., Brown, P. O. \& Eide, D. J. (2000). Genome-wide characterization of the Zap1p zinc-responsive regulon in yeast. Proc Natl Acad Sci USA 97, 7957-7962.

Manger, I. D. \& Relman, D. A. (2000). How the host 'sees' pathogens: global gene expression responses to infection. Curr Opin Immunol 12, 215-218.

Maron, D. M. \& Ames, B. N. (1983). Revised methods for the Salmonella mutagenicity test. Mutat Res 113, 173-215.

Marton, M. J., DeRisi, J. L., Bennett, H. A. \& 11 other authors (1998). Drug target validation and identification of secondary 
drug target effects using DNA microarrays. Nature Med 4, 1293-301.

Nelson, K. E., Paulsen, I. T., Heidelberg, J. F. \& Fraser, C. M. (2000). Status of genome projects for nonpathogenic bacteria and archaea. Nature Biotechnol 18, 1049-1054.

Ochman, H., Lawrence, J. G. \& Groisman, E. A. (2000). Lateral gene transfer and the nature of bacterial innovation. Nature 405, 299-304.

Oh, M. K. \& Liao, J. C. (2000). Gene expression profiling by DNA microarrays and metabolic fluxes in Escherichia coli. Biotechnol Prog 16, 278-286.

Pennisi, E. (2000). Microbial genomics. Culling genes early yields rich harvest. Science 287, 1572-1573.

Posas, F., Chambers, J. R., Heyman, J. A., Hoeffler, J. P., de Nadal, E. \& Arino, J. (2000). The transcriptional response of yeast to saline stress. J Biol Chem 275, 17249-17255.

Primig, M., Williams, R. M., Winzeler, E. A., Tevzadze, G. G., Conway, A. R., Hwang, S. Y., Davis, R. W. \& Esposito, R. E. (2000). The core meiotic transcriptome in budding yeasts. Nature Genet 26, 415-423.

Py, B., Higgins, C. F., Krisch, H. M. \& Carpousis, A. J. (1996). A DEAD-box RNA helicase in the Escherichia coli RNA degradosome. Nature 381, 169-172.

Ren, B., Robert, F., Wyrick, J. J. \& 11 other authors (2000). Genome-wide location and function of DNA binding proteins. Science 290, 2306-2309.

Richmond, C. S., Glasner, J. D., Mau, R., Jin, H. \& Blattner, F. R. (1999). Genome-wide expression profiling in Escherichia coli K12. Nucleic Acids Res 27, 3821-3835.

Riehle, M. M., Bennett, A. F. \& Long, A. D. (2001). Genetic architecture of thermal adaptation in Escherichia coli. Proc Natl Acad Sci U S A 9, 525-530.

Rimini, R., Jansson, B., Feger, G. \& 8 other authors (2000). Global analysis of transcription kinetics during competence development in Streptococcus pneumoniae using high density DNA arrays. Mol Microbiol 36, 1279-1292.

Rosamond, J. \& Allsop, A. (2000). Harnessing the power of the genome in the search for new antibiotics. Science 287, 1973-1976.

Rosenberger, C. M., Scott, M. G., Gold, M. R., Hancock, R. E. \& Finlay, B. B. (2000). Salmonella typhimurium infection and lipopolysaccharide stimulation induce similar changes in macrophage gene expression. J Immunol 164, 5894-5904.

Ross-Macdonald, P., Coelho, P. S., Roemer, T. \& 15 other authors (1999). Large-scale analysis of the yeast genome by transposon tagging and gene disruption. Nature 402, 413-418.

de Saizieu, A., Gardes, C., Flint, N., Wagner, C., Kamber, M., Mitchell, T. J., Keck, W., Amrein, K. E. \& Lange, R. (2000). Microarray-based identification of a novel Streptococcus pneumoniae regulon controlled by an autoinduced peptide. $J$ Bacteriol 182, 4696-4703.

Salama, N., Guillemin, K., McDaniel, T. K., Sherlock, G., Tompkins, L. \& Falkow, S. (2000). A whole-genome microarray reveals genetic diversity among Helicobacter pylori strains. Proc Natl Acad Sci U S A 97, 14668-14673.

Sarkar, N. (1996). Polyadenylation of mRNA in bacteria. Microbiology 142, 3125-3133.

Schena, M., Shalon, D., Davis, R. W. \& Brown, P. O. (1995). Quantitative monitoring of gene expression patterns with a complementary DNA microarray. Science 270, 467-470.

Shalon, D., Smith, S. J. \& Brown, P. O. (1996). A DNA microarray system for analyzing complex DNA samples using two-color fluorescent probe hybridization. Genome Res 6, 639-645.

Southern, E. M. (1975). Detection of specific sequences among DNA fragments separated by gel electrophoresis. J Mol Biol 98, 503-517.

Spellman, P. T., Sherlock, G., Zhang, M. Q., lyer, V. R., Anders, K., Eisen, M. B., Brown, P. O., Botstein, D. \& Futcher, B. (1998). Comprehensive identification of cell cycle-regulated genes of the yeast Saccharomyces cerevisiae by microarray hybridization. Mol Biol Cell 9, 3273-3297.

Spradling, A. C., Stern, D., Beaton, A., Rhem, E. J., Laverty, T., Mozden, N., Misra, S. \& Rubin, G. M. (1999). The Berkeley Drosophila Genome Project gene disruption project: single Pelement insertions mutating $25 \%$ of vital Drosophila genes. Genetics 153, 135-177.

Sudarsanam, P., lyer, V. R., Brown, P. O. \& Winston, F. (2000). Whole-genome expression analysis of $s n f / s w i$ mutants of Saccharomyces cerevisiae. Proc Natl Acad Sci USA 97, 3364-3369.

Talaat, A. M., Hunter, P. \& Johnston, S. A. (2000). Genomedirected primers for selective labeling of bacterial transcripts for DNA microarray analysis. Nature Biotechnol 18, 679-682.

Tang, Y. \& Guest, J. R. (1999). Direct evidence for mRNA binding and post-transcriptional regulation by Escherichia coli aconitases. Microbiology 145, 3069-3079.

Tao, H., Bausch, C., Richmond, C., Blattner, F. R. \& Conway, T. (1999). Functional genomics: expression analysis of Escherichia coli growing on minimal and rich media. J Bacteriol 181, 6425-6440.

Thompson, A., Lucchini, S. \& Hinton, J. C. D. (2001). It's easy to build your own microarrayer! Trends Microbiol 9, 154-156.

Troesch, A., Nguyen, H., Miyada, C. G., Desvarenne, S., Gingeras, T. R., Kaplan, P. M., Cros, P. \& Mabilat, C. (1999). Mycobacterium species identification and rifampin resistance testing with highdensity DNA probe arrays. J Clin Microbiol 37, 49-55.

Velculescu, V. E., Zhang, L., Zhou, W., Vogelstein, J., Basrai, M. A., Bassett, D. E. J., Hieter, P., Vogelstein, B. \& Kinzler, K. W. (1997). Characterization of the yeast transcriptome. Cell 88, 243-251.

Vishwanath, R. I., Horak, C. E., Scafe, C. S., Botstein, D., Snyder, M. \& Brown, P. O. (2001). Genomic binding sites of the yeast cellcycle transcription factors SBF and MBF. Nature 409, 533-538.

Wang, E., Miller, L. D., Ohnmacht, G. A., Liu, E. T. \& Marincola, F. M. (2000). High-fidelity mRNA amplification for gene profiling. Nature Biotechnol 18, 457-459.

Wasinger, V. C., Cordwell, S. J., Cerpa-Poljak, A. \& 7 other authors (1995). Progress with gene-product mapping of the Mollicutes: Mycoplasma genitalium. Electrophoresis 16, 1090-1094.

Wei, Y., Lee, J. M., Richmond, C., Blattner, F. R., Rafalski, J. A. \& LaRossa, R. A. (2001). High-density microarray-mediated gene expression profiling of Escherichia coli. J Bacteriol 183, 545-556.

Wilson, M., DeRisi, J., Kristensen, H. H., Imboden, P., Rane, S., Brown, P. O. \& Schoolnik, G. K. (1999). Exploring drug-induced alterations in gene expression in Mycobacterium tuberculosis by microarray hybridization. Proc Natl Acad Sci USA 96, 12833-12838.

Winzeler, E. A., Richards, D. R., Conway, A. R. \& 8 other authors (1998). Direct allelic variation scanning of the yeast genome. Science 281, 1194-1197. 
Winzeler, E. A., Lee, B., McCusker, J. H. \& Davis, R. W. (1999a). Whole genome genetic-typing in yeast using high-density oligonucleotide arrays. Parasitology 118 Suppl., S73-S80.

Winzeler, E. A., Shoemaker, D. D., Astromoff, A. \& 49 other authors (1999b). Functional characterization of the S. cerevisiae genome by gene deletion and parallel analysis. Science 285, 901-906.

Wodicka, L., Dong, H., Mittmann, M., Ho, M. H. \& Lockhart, D. J. (1997). Genome-wide expression monitoring in Saccharomyces cerevisiae. Nature Biotechnol 15, 1359-1367.

Wolfsberg, T. G., Gabrielian, A. E., Campbell, M. J., Cho, R. J., Spouge, J. L. \& Landsman, D. (1999). Candidate regulatory sequence elements for cell cycle-dependent transcription in Saccharomyces cerevisiae. Genome Res 9, 775-792.

Wyrick, J. J., Holstege, F. C., Jennings, E. G., Causton, H. C.,
Shore, D., Grunstein, M., Lander, E. S. \& Young, R. A. (1999). Chromosomal landscape of nucleosome-dependent gene expression and silencing in yeast. Nature 402, 418-421.

Ye, R. W., Tao, W., Bedzyk, L., Young, T., Chen, M. \& Li, L. (2000). Global gene expression profiles of Bacillus subtilis grown under anaerobic conditions. J Bacteriol 182, 4458-4465.

Yun, C. W., Ferea, T., Rashford, J., Ardon, O., Brown, P. O., Botstein, D., Kaplan, J. \& Philpott, C. C. (2000). Desferrioxaminemediated iron uptake in Saccharomyces cerevisiae. Evidence for two pathways of iron uptake. J Biol Chem 275, 10709-10715.

Zhang, M. Q. (1999). Promoter analysis of co-regulated genes in the yeast genome. Comput Chem 23, 233-250.

Zweiger, G. (1999). Knowledge discovery in gene-expressionmicroarray data: mining the information output of the genome. Trends Biotechnol 17, 429-436. 